\title{
Entrepreneurial Marketing dan Trust Terhadap Marketing Performance
}

\author{
Aditya Liliyan \\ Sekolah Tinggi Ilmu Ekonomi Surakarta \\ aditya.liliyan@gmail.com
}

\begin{abstract}
The purpose of this research is to determine the level of entrepreneurial marketing and trust carried out by SMEs and to contribute to literature and conceptual models on the effect of entrepreneurial marketing and trust on marketing performance. The sample in this study were SMEs in the handicraft sector in Rembang, Central Java. The number of samples studied was 200 samples. The sampling technique used purposive sampling. The sample criteria are SMEs that have been running a business for at least 3 (three) years. This is because in measuring the dimensions of marketing performance there are several indicators of the level of achievement of marketing performance each year, at least for a minimum of 3 years it can be seen the marketing performance of these SMEs. Data analysis using multiple regression modeling. The results show that entrepreneurial marketing has a significant effect on marketing performance, trust has a significant effect on marketing performance, entrepreneurial marketing and trust simultaneously have a significant effect on marketing performance.
\end{abstract}

Keywords : entrepreneurial marketing; trust; marketing performance

\begin{abstract}
ABSTRAK
Tujuan dari penelitian ini adalah untuk mengetahui tingkat pemasaran kewirausahaan dan kepercayaan yang dilakukan oleh UMKM serta memberikan kontribusi terhadap literatur dan model konseptual tentang pengaruh pemasaran kewirausahaan dan kepercayaan terhadap kinerja pemasaran. Sampel dalam penelitian ini adalah UMKM sektor kerajinan di Rembang Jawa Tengah. Jumlah sampel yang diteliti sebanyak 200 sampel. Teknik pengambilan sampel menggunakan purposive sampling. Kriteria sampel adalah UMKM yang sudah menjalankan usaha minimal 3 (tiga) tahun. Hal ini dikarenakan dalam mengukur dimensi kinerja pemasaran terdapat beberapa indikator tingkat pencapaian kinerja pemasaran setiap tahunnya, minimal minimal 3 tahun dapat dilihat kinerja pemasaran dari UMKM tersebut. Analisis data menggunakan model regresi berganda. Hasil penelitian menunjukkan bahwa pemasaran kewirausahaan berpengaruh signifikan terhadap kinerja pemasaran, kepercayaan berpengaruh signifikan terhadap kinerja pemasaran, pemasaran kewirausahaan dan kepercayaan secara simultan berpengaruh signifikan terhadap kinerja pemasaran.
\end{abstract}

Kata kunci: pemasaran kewirausahaan; kepercayaan; kinerja pemasaran 


\section{PENDAHULUAN}

Pada tahun 2015, negara anggota ASEAN telah menyetujui Cetak Biru Masyarakat Ekonomi ASEAN 2025. Cetak Biru MEA 2025 akan terbangun di atas Cetak Biru MEA 2015 yang terdiri dari lima karakteristik yang saling terkait dan saling menguatkan, yaitu: (a) ekonomi yang terpadu dan terintegrasi penuh; (b) ASEAN yang berdaya saing, inovatif, dan dinamis; (c) Peningkatan konektivitas dan kerja sama sektoral; (d) ASEAN yang tangguh, inklusif, serta berorientasi dan berpusat pada masyarakat; dan (e) ASEAN yang global. MEA 2015 bertujuan meningkatkan kesejahteraan ASEAN yang memiliki karakteristik sebagai pasar dan basis produksi tunggal, kawasan ASEAN yang lebih dinamis dan berdaya saing, memiliki pembangunan yang setara, serta mempercepat keterpaduan ekonomi di kawasan ASEAN dan dengan kawasan di luar ASEAN. (Sumber: Sekretariat Nasional ASEAN-Indonesia).

Pilar Masyarakat Ekonomi ASEAN (MEA) adalah bentuk kerja sama untuk memperdalam dan memperluas integrasi ekonomi di kawasan ASEAN dan dengan kawasan di luar ASEAN. Empat Pilar MEA yaitu : (1) pasar dan basis produksi tunggal; (2) kawasan ekonomi berdaya saing tinggi; (3) kawasan dengan pembangunan ekonomi yang merata dan berkeadilan; (4) kawasan yang terintegrasi dengan ekonomi global. (Sumber : ASEAN Economic Ministers Meeting Tahun 2006).

Untuk mewujudkan keempat pilar tersebut, bukan saja pemerintah yang harus bekerja, akan tetapi stakeholder yang lainnya termasuk dunia usaha juga sangatlah penting. Khusus dalam rangka mewujudkan pilar ketiga, yaitu kawasan dengan pembangunan ekonomi yang setara, maka pemberdayaan UMKM menjadi sangat penting, selain masalah mengatasi kesenjangan dan konektivitas.

UMKM berkontribusi besar terhadap perekonomian Indonesia maupun ASEAN. Pada tahun 2016, sekitar 96 persen bentuk usaha di ASEAN adalah Usaha Mikro, Kecil dan Menengah (UMKM) dengan kontribusi pada produk domestik bruto (PDB) sekitar 30\% sampai 57\%; dan menyerap tenaga kerja sekitar 50\% sampai 95\%. Sementara di Indonesia, UMKM menyumbang 99,98\% unit usaha dengan kontribusi pada PDB nasional sebesar 57\% PDB nasional; dan menyerap lebih dari 97\% tenaga kerja domestik. Dalam kerangka ini, peran UMKM menjadi sangat penting sebagai pendorong utama penciptaan lapangan pekerjaan dan pertumbuhan ekonomi, baik pada tataran nasional maupun regional. (Sumber : Majalah Masyarakat ASEAN edisi 12/ Juni Tahun 2016)

Kementerian KUKM RI telah meneliti kesiapan UMKM Indonesia menghadapi MEA pada tahun 2015. Metodologi riset mengadopsi model McKinsey-GE dengan dua dimensi (faktor), yaitu faktor lingkungan strategis internal dan faktor lingkungan strategis eksternal. 
Faktor lingkungan internal juga dapat mencerminkan kekuatan bisnis UMKM dan faktor lingkungan eksternal sebagai daya tarik industrialnya. Sampel UMKM sebanyak 255 unit tersebar di enam provinsi, dengan penerapan "likert scale" dari skor 1-5 yang terboboti menjadi “indeks performa kesiapan" atau IPK dimana IPK < 2,0 (Tidak Siap), IPK 2,0 - 3,00 (Kurang Siap), IPK 3,00 - 4,00 (Cukup Siap), IPK 4,00 - 4,50 (Siap), dan IPK $\geq 4,50$ (Sangat Siap), terungkap seberapa jauh tingkat kesiapan UMKM dalam menghadapi MEA

Tabel 1

Indeks Performa Kesiapan UMKM Indonesia Menghadapi MEA

\begin{tabular}{clc} 
No. & \multicolumn{1}{c}{ Uraian } & Indeks \\
\hline 1. & Indeks Performa Kesiapan UMKM (IPKU) & 2,2495 \\
\hline 2. & IPK UMKM Minimum & 1,2870 \\
\hline 3. & IPK UMKM Mkasimum & 2,2925 \\
& Estimasi Interval (pada $\alpha-\% 5)$ & \\
\hline 4. & Batas Bawah & 2,1192 \\
\hline 5. & Batas Atas & 2,2999 \\
\hline 6. & Margin of Error $(\mathrm{MoE})(\%)$ & $2,24 \%$ \\
\hline
\end{tabular}

(Sumber : Kementrian KUKM RI Tahun 2015)

Pada Tabel 1 terlihat IPK UMKM (IPKU) hasil penelitian kesiapan UMKM menghadapi MEA. IPKU adalah 2,25 dimana IPKU minimum hanya 1,29 dan maksimum 2,29. UMKM pada umumnya termasuk kategori "Kurang Siap" menghadapi MEA. Posisi kekurangsiapan UMKM menghadapi MEA agak riskan karena cenderung mendekati kategori "Tidak Siap".

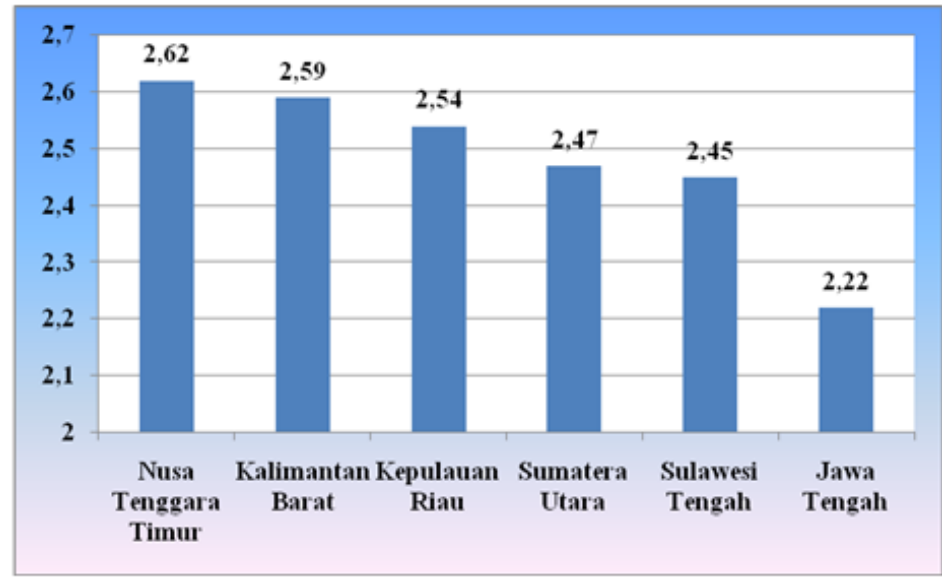

Gambar 1.

Indeks Kesiapan UMKM Menghadapi MEA Berdasarkan Provinsi

(Sumber : Kementrian KUKM RI Tahun 2015) 
Dari kategori "Kurang Siap" menghadapi MEA terungkap bahwa NTT adalah terbaik performanya dibandingkan provinsi lain, disusul oleh Kalimantan Barat, Kepulauan Riau, Sumatera Utara, Sulawesi Tengah. UMKM di Provinsi Jawa Tengah terjelek performa kesiapannya dengan IPKU 2,22. Dengan infrastruktur Jawa Tengah dan Pulau Jawa umumnya yang jauh lebih memadai dibandingkan provinsi sampel lainnya disertai oleh interaksi yang lebih tinggi antara pusat dan daerah, ternyata belum sepenuhnya menjadikan UMKM Jawa Tengah siap menghadapi MEA.

Globalisasi saat ini telah mendorong terjadinya berbagai perubahan di dalam sektor perdagangan yang mengindikasikan telah diterapkannya perdagangan bebas. Mengawali tahun 2010 ACFTA (ASEAN plus CHINA Free Trade Area). ACFTA berawal dari pertemuan kepalakepala pemerintahan Negara-Negara ASEAN dan China pada tanggal 6 November 2001 di Bandar Seri Begawan Brunai Darussalam yang menginginkan hubungan ekonomi yang lebih luas, intensif dan tidak ada hambatan. Setahun kemudian, tanggal 5 November 2002 pertemuan berikut di kota Pnompenh Kamboja untuk menandatangani perjanjian persetujuan membangun ACFTA dalam 10 tahun, dimulai 2010. (Sumber : kemendag.co.id).

Adanya pasar bebas yang mempermudah para importir membawa semakin banyak aneka ragam pilihan barang impor dari berbagai negara ke Indonesia salah satunya produk china dengan konsep yang mementingkan kuantitas dibandingkan kualitas menyebabkan terdesaknya posisi para produsen-produsen barang lokal terutama indurtri-industri kecil, UMKM, dan industri rumah tangga. Terdesaknya para produsen dalam negeri disebabkan oleh berpindahnya selera masyarakat yang kemudian mengurangi quantity produksi dan akhirnya berpengaruh pada pendapatan yang diperoleh. Efek lebih lanjutnya adalah keterdesakan produsen dalam hal pendapatan yang pada akhirnya mungkin akan beresiko pada kelangsungan usaha tersebut. (Sumber : E-Paper Disperindag Jateng Tahun 2014).

Seluruh UMKM di Indonesia pada saat ini dihadapkan pada persaingan yang ketat sudah selayaknya UMKM tersebut ditingkatkan. Beberapa karakteristik yang melekat pada sebagian besar UMKM dan sekaligus menjadi sumber permasalahan diantarnya : (1) Rendahnya kualitas sumber daya manusia yang bekerja pada sektor UMKM; (2) Rendahnya produktivitas tenaga kerja yang berimbas pada rendahnya upah; (3) Kualitas barang yang dihasilkan relatif rendah; (4) Kurangnya inovasi dan adopsi teknologi-teknologi baru dalam produksi; (5) Lemahnya struktur permodalan dan kurangnya akses kepada sumber pembiayaan; (6) Kurangnya akses pemasaran ke pasar yang potensial. Tiga sisi utama yang harus di perbaiki untuk mengembangkan UMKM : (a) Pengembangan dan peningkatan kualitas produk; (b) Peningkatan permodalan dan akses terhadap sumber pembiayaan; (c) Pengembangan pasar 
(market dan marketing) produk UMKM. (Sumber: Kebijakan BI dalam Pengembangan UMKM Tahun 2011).



Gambar 2.

Permasalahan Utama yang di hadapi UMKM

(Sumber : Kebijakan BI dalam Pengembangan UMKM Tahun 2011)

Persaingan yang ketat ini juga di alami oleh pelaku UMKM salah satunya dalam bidang kerajinan. Kementerian Perindustrian terus memacu daya saing industri kerajinan nasional agar semakin kompetitif di kancah global. Pasalnya, produk unggulan kriya dari Indonesia cukup banyak diminati oleh konsumen mancanengara jika dilihat dari data nilai ekspor yang dihasilkan tahun 2017 sebesar USD 776 juta, lebih tinggi dibanding capaian tahun sebelumnya di angka USD 747 juta. Untuk itu pelaku industri kreatif bidang kerajinan semakin dituntut untuk tidak hanya mampu bersaing secara sehat di pasar negeri sendiri serta unggul dari barang impor, namun juga diharapkan dapat memenuhi pasar mancanegara. Terlebih lagi industri kerajinan merupakan sektor padat karya berorientasi ekspor. Kekuatan industri kerajinan nasional terletak pada sumber bahan baku lokal yang melimpah dengan didukung oleh keragaman corak dan desain, terutama yang berciri khas nusantara. Selain itu, para pengrajin kita tersebar di seluruh wilayah Indonesia dengan memiliki keterampilan yang andal di bidang masing-masing. (Sumber : Kemenprin.co.id).

Salah satu daerah yang memiliki potensi dari bidang kerajinannya adalah Kabupaten Rembang. Berbagai jenis produk kerajinan yang dihasilkan UMKM di Kabupaten Rembang memiliki jenis yang sangat unik dan menarik untuk dapat dikembangkan sehingga dapat dijadikan obyek yang dapat menarik investor untuk dapat masuk di Kabupaten Rembang. Potensi pada bidang kerajinan yang dapat dikembangkan diharapkan dapat dijadikan keunggulan komperatif yang tidak dimiliki oleh daerah lain. Industri kerajinan tersebut antara lain kerajinan batik, bordir, kuningan, kayu, anyaman, pembuatan tas, dompet, sabuk dan lain- 
lain. Potensi ini diharapkan dapat mendongkrak sektor ekonomi riil dalam era otonomi daerah sekarang ini.

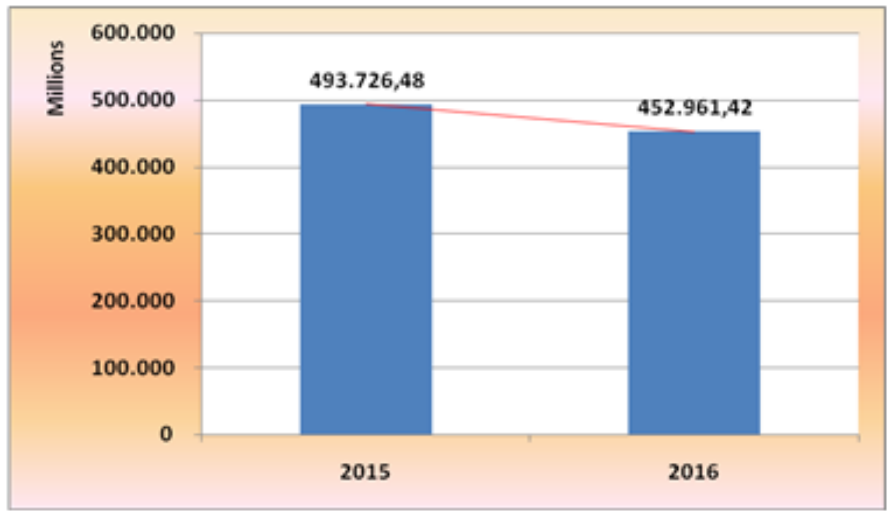

Gambar 3.

Omset/Tahun UMKM Bidang Kerajinan

Di Kabupaten Rembang

(Sumber : Disperindagkop Kab. Rembang Tahun 2015 \& 2016)

Berdasarkan gambar 3 diatas dapat terlihat omset/tahun UMKM bidang kerajinan di Kabupaten Rembang pada tahun 2015 sebesar Rp. 493.726.480.000,- dan 2016 sebesar Rp. 452.961.420.000,- terjadi penurunan omset/tahun UMKM bidang kerajinan. Hal ini dapat diindikasikan bahwa terjadinya penurunan kinerja pemasaran UMKM bidang kerajinan di Kabupaten Rembang.

Kinerja pemasaran merupakan ukuran yang dipakai oleh manajemen untuk menilai dan mengevaluasi effektifitas dan pengembalian dari aktifitas pemasaran. Untuk meningkatkan kinerja pemasaran tersebut, dibutuhkan metode dan strategi pemasaran yang tepat. Salah satu pendekatan yang dapat digunakan saat ini dalam penerapan pemasaran produk oleh pelaku usaha kecil menengah adalah konsep entrepreneurial marketing. Konsep entrepreneurial marketing pada dasarnya merupakan disiplin ilmu yang mempelajari tentang nilai, kemampuan (ability) dan perilaku seseorang wirausaha dalam menghadapi berbagai permasalahan terkait dalam usaha mendapatkan peluang usaha yang dilakukan (Stokes, 2000). Pendekatan entrepreneurial marketing merupakan pendekatan konsep yang tepat ditinjau dari keterbatasan sumber daya dan permasalahan yang ada pada UMKM.

Apabila setiap pelaku UMKM di bidang kerajinan khususnya di Kabupaten Rembang menerapkan konsep entrepreneurial marketing diharapkan dapat meningkatkan kinerja pemasaran UMKM tersebut. Nantinya dengan kinerja pemasaran yang baik akan dapat meningkatkan profitabilitas UMKM. Untuk meingkatkan kinerja pemasaran para pelaku 
UMKM juga dapat meningkatkan trust kepada pelanggan. Trust merupakan fondasi dari bisnis. Suatu transaksi bisnis antara dua pihak atau lebih akan terjadi apabila masing-masing saling mempercayai. Berdasarkan hal diatas dengan dilakukannya entrepreneurial marketing dan meningkatkan trust diharapkan dapat meningkatkan kinerja pemasaran UMKM khususnya bidang kerajinan di Kabupaten Rembang.

\section{Entrepreneurial Marketing}

Entrepreneurial marketing merupakan konsep yang awalnya muncul pada pelaku usaha skala kecil atau pelaku usaha yang baru memulai bisnisnya. Entrepreneurial marketing merupakan pendekatan konsep yang lebih sesuai ditinjau dari keterbatasan sumber daya dan permasalahan yang ada pada UMKM. (Stokes, 2000). Menurut Morris et al. (2002) entrepreneurial marketing sebagai sebuah sikap proaktif dalam mengidentifikasi dan mengeksploitasi berbagai peluang dalam rangka mendapatkan dan mempertahankan pelanggan yang menguntungkan melalui berbagai pendekatan inovatif untuk mengelola risiko, mengoptimalkan sumber daya dan menciptakan nilai.

Berbagai variasi telah muncul pada penelitian entrepreneurial marketing. Keragaman tersebut terjadi bukan hanya pada definisi entrepreneurial marketing, tetapi juga menyangkut metode pengukuran yang digunakan (dimensi). Menurut Stokes (2000) menegaskan terdapat empat prinsip entrepreneurial marketing yang terbagi atas konsep, strategi, metode, dan intelejensi pasar.

Entrepreneurial marketing adalah sebuah fungsi organisasional dan serangkain proses untuk menciptakan, mengkomunikasikan dan menghantarkan nilai bagi pelanggan dan untuk mengelola hubungan dengan pelanggan guna memberikan manfaat bagi organisasi dan pemegang saham. Entrepreneurial marketing dikarakteristikan melalui inovasi, pengambilan resiko, dan sikap proaktif (Kraus et al., 2009). Entrepreneurial marketing merepresentasikan sesuatu yang lebih kompleks dari pada sekedar menyediakan konsep dan alat untuk memposisikan dan menciptakan keunggulan bersaing bagi inovasi baru. Entrepreneurial marketing adalah spirit sebuah orientasi yang disertai proses pencarian peluang secara agresif dalam pengenalan dan pertumbuhan usaha dengan menciptakan nilai bagi pelanggan melalui hubungan dengan menggunakan inovasi, kreativitas, penjualan, peleburan pasar, jalinan kerjasama dan fleksibilitas.

Terdapat perbedaan antara strategi pemasaran tradisional dan strategi entrepreneurial marketing termasuk juga dalam konsep dan intelegensi pasar. Hal tersebut dapat dilihat dalam tabel prinsip pemasaran tradisonal dan entrepreneurial marketing. 
Tabel 2.

Prinsip Pemasaran Tradisional dan Entrepreneurial Marketing

\begin{tabular}{|c|c|c|}
\hline $\begin{array}{c}\text { Prinsip } \\
\text { Pemasaran }\end{array}$ & Pemasaran Tradisional & Entrepreneurial Marketing \\
\hline Konsep & $\begin{array}{l}\text { Berorientasi konsumen, dorongan } \\
\text { pasar, pengembangan produk. }\end{array}$ & $\begin{array}{l}\text { Berorientasi inovasi, dorongan ide, } \\
\text { taksiran intuitif tentang kebutuhan } \\
\text { pasar }\end{array}$ \\
\hline Strategi & $\begin{array}{l}\text { Segmentasi top-down, } \\
\text { targeting dan positioning }\end{array}$ & $\begin{array}{l}\text { Target bottom-up dari konsumen dan } \\
\text { kelompok pengaruh lainnya }\end{array}$ \\
\hline Metode & $\begin{array}{l}\text { Bauran pemasaran, } \\
4 \mathrm{P} / 7 \mathrm{P} \text {. }\end{array}$ & $\begin{array}{l}\text { Metode pemasaran interaktif, } \\
\text { pemasaran dari mulut ke mulut } \\
(\text { WOM). }\end{array}$ \\
\hline $\begin{array}{l}\text { Intelegensi } \\
\text { Pasar }\end{array}$ & $\begin{array}{l}\text { Penelitian formal dan sistem } \\
\text { intelegensi. }\end{array}$ & $\begin{array}{l}\text { Jaringan informal dan pengumpulan } \\
\text { informasi }\end{array}$ \\
\hline
\end{tabular}

(Sumber : Stokes, 2000)

Kajian dimensi entrepreneurial marketing, pada awalnya diajukan oleh Morris et al. (2002) yang mencakup tujuh dimensi diantaranya :

1. Proaktif (proactiveness)

2. Pengambilan resiko (calculated risk taking)

3. Tingkat inovasi (innovativeness)

4. Fokus pada pelanggan (opportunity focus)

5. Pemanfaatan sumber daya (resources leveraging)

6. Intensitas konsumen (consumer intensity)

7. Penciptaan nilai (value creation)

Dimensi proaktif, pengambilan resiko, tingkat inovasi, dan fokus pada peluang diturunkan dari kerangka kerja orientasi kewirausahaan. Dimensi intensitas konsumen dan penciptaan nilai diturunkan dari kerangka kerja orientasi pemasaran. Dimensi pemanfaatan sumber daya merupakan element tunggal yang menekankan pada perspektif pemasaran pada khususnya guerilla marketing atau pemasaran gerilya. Guerrilla marketing dikembangkan pada tahun 1993 dengan menekankan pada dimensi atau karakteristik : biaya rendah, komunikasi efektif, kemitraan, dan pemanfaatan sumber daya (Morris et al., 2002). 
Niehm et al. (2013) melakukan pengembangan skala dan validasi terhadap konstruk atau dimensi entrepreneurial marketing yang diadopsi dari Morris et al (2002). Dari hasil peneilitannya menunjukan bahwa dimensi orientasi proaktif (proactive orientation) dan pengendalian peluang (opprtunity driven) tergabung dalam satu dimensi yang disebut kewaspadaan peluang (opprtunity vigilance). Intensitas pelanggan (consumer intensity) dan fokus pada inovasi (innovation focused) tergabung dalam satu dimensi yakni inovasi konsumen sentris (consumer-centris innovation). Dimensi penciptaan nilai (value creation) dan pengelolaan resiko (risk management) sebagai bagian dari dimensi entrepreneurial marketing seperti halnya pada kerangka kerja Morris et al. (2002).

\section{Trust (kepercayaan)}

Kepercayaan timbul dari proses yang panjang. Jika kepercayaan sudah ada antara pelanggan dan perusahaan, maka upaya untuk membina hubungan kerjasama akan lebih mudah. Kepercayaan yang timbul ditunjukkan oleh kredibilitas yang diterima pihak lain karena memiliki keahlian yang diinginkan untuk melakukan suatu tugas. Trust merupakan fondasi dari bisnis. Suatu transaksi bisnis antara dua pihak atau lebih akan terjadi apabila masing-masing saling mempercayai. Kepercayaan (trust) ini tidak begitu saja dapat diakui oleh pihak lain/mitra bisnis, melainkan harus dibangun mulai dari awal dan dapat dibuktikan. Trust didefinisikan dengan berbagai pendekatan. Pada awalnya trust banyak dikaji dari disiplin psikologi, karena hal ini berkaitan dengan sikap seseorang. (Mukherjee dan Nath, 2003).

Kepercayaan (trust) membuat seseorang untuk menentukan suatu perilaku tertentu karena dia meyakini bahwa mitranya dalam melakukan transaksi akan memberikan apa yang dia harapkan dan inginkan. Seseorang mendapat kepercayaan melalui tindakan dan belajar dari sesuatu, mempengaruhi perilaku pembelian meraka dan loyalitas. Kepercayaan ialah perantara kunci dalam membangun hubungan jangka panjang bagi pelanggan yang memiliki orientasi hubungan yang tinggi terhadap organisasi (Morgan dan Hunt, 1994).

Kepercayaan melibatkan kesediaan seseorang untuk berperilaku tertentu karena dia meyakini bahwa mitranya dalam melakukan transaksi akan memberikan apa yang dia harapkan. Hal ini menunjukkan bahwa jika satu pihak mempercayai pihak lainnya, akan dimungkinkan untuk membentuk sebuah perilaku positif dan niat baik. Oleh karena itu saat konsumen memiliki kepercayaan kepada sebuah produk atau jasa tertentu, maka konsumen memiliki niat untuk membeli produk atau jasa tersebut. (Lau dan Lee, 1999).

Menurut Pavlou and Geffen (2002) kepercayaan adalah penilaian hubungan seseorang dengan orang lain yang akan melakukan transaksi tertentu menurut harapan orang 
kepercayaannya dalam suatu lingkungan yang penuh ketidakpastian. Kepercayaan adalah kemauan seseorang untuk peka terhadap tindakan orang lain berdasarkan pada harapan bahwa orang lain akan melakukan tindakan tertentu pada orang yang mempercayainya, tanpa tergantung pada kemampuannya untuk mengawasi dan mengendalikannya. (Meyer et al., 1995). Berdasarkan definisi di atas, maka dapat dinyatakan bahwa kepercayaan (trust) adalah keyakinan pihak tertentu terhadap yang lain dalam melakukan hubungan transaksi berdasarkan suatu keyakinan bahwa orang yang dipercayainya tersebut akan memenuhi segala kewajibannya secara baik sesuai yang diharapkan.

Dimensi trust menurut Mayer et al. (1995) faktor yang membentuk kepercayaan seseorang terhadap yang lain ada tiga yaitu kemampuan (ability), kebaikan hati (benevolence), dan integritas (integrity). Ketiga faktor tersebut dapat dijelaskan sebagai berikut:

1. Kemampuan (ability). Kemampuan mengacu pada kompetensi dan karakteristik penjual/organisasi dalam mempengaruhi dan mengotorisasi wilayah yang spesifik. Dalam hal ini, bagaimana penjual mampu menyediakan, melayani, sampai mengamankan transaki dari gangguan pihak lain. Artinya bahwa konsumen memperoleh jaminan kepuasan dan keamanan dari penjual dalam melakukan transaksi. Kim et al. (2003) menyatakan bahwa ability meliputi kompetensi, pengalaman, pengesahan institusional, dan kemampuam dalam ilmu pengetahuan.

2. Kebaikan hati (benevolence). Kebaikan hati merupakan kemauan penjual dalam memberikan kepuasan yang saling menguntungkan antara dirinya dengan konsumen. Profit yang diperoleh penjual dapat dimaksimumkan, tetapi kepuasan konsumen juga tinggi. Penjual bukan semata-mata mengejar profit maksimum semata, melainkan juga memiliki perhatian yang besar dalam mewujudkan kepuasan konsumen. Menurut Kim et al. (2003) benevolence meliputi perhatian, empati, keyakinan, dan daya terima.

3. Integritas (integrity). Integritas berkaitan dengan bagaimana perilaku atau kebiasaan penjual dalam menjalankan bisnisnya. Informasi yang diberikan kepada konsumen apakah benar sesuai dengan fakta atau tidak. Kualitas produk yang dijual apakah dapat dipercaya atau tidak. Kim et al. (2003) mengemukakan bahwa integritas dapat dilihat dari sudut kewajaran (fairness), pemenuhan (fulfillment), kesetiaan (loyalty), keterusterangan (honestly), keterkaitan (dependability), dan kehandalan (reliabilty). 


\section{Marketing Performance}

Menurut Walker (2004) kinerja pemasaran merupakan ukuran yang dipakai oleh manajemen untuk menilai dan mengevaluasi efektifitas dan pengembalian dari aktifitas pemasaran, khususnya sales dan market share. Dimensi kinerja pemasaran penelitian diukur menggunakan indikator pertumbuhan penjualan, pendapatan, pangsa pasar, kemampuan untuk mendapatkan pelanggan baru, meningkatkan penjualan ke pelanggan yang ada, dan biaya rendah (Muangkhot dan Ussahawanitchakit, 2015; Dewi dan Darma, 2019; Kanten dan Darma, 2017; Adnyana dan Darma, 2015).

Sedangkan konsep dimensi kinerja pemasaran dalam penelitian yang dilakukan oleh Ogbuji et al. (2014) diukur menggunakan indikator sales growth, sales volumes, dan profitability. Kartawinata dan Wardhana (2013) Mengukur variabel kinerja pemasaran dengan dimensi sales volumes, profit, market share.

Suherly et al. (2014) dalam mengukur kinerja pemasaran menggunkan konsep dengan indikator sales growth, sales volumes, dan profitability. Menguraikannya sebagai berikut : 1) Sales growth : dimana jumlah unit penjualan produk meningkat. Unit produk yang dijual di satu tahun dibandingkan dengan tahun-tahun sebelumnya. Dari penjelasan ini dapat disimpulkan tentang dimensi dari pertumbuhan penjualan variabel terdiri dari persentase penjualan sebelum, sekarang dan di masa depan. 2) Sales volumes : volume penjualan yang menggambarkan jumlah unit produk yang dijual dalam satu jangka waktu, biasanya satu tahun lamanya. Dari sini dapat disimpulkan dalam penjelasan untuk dimensi volume penjualan variabel yang terdiri dari sejumlah besar produk ditawarkan, sejumlah besar unit produk terjual dan durasi penjualan. 3) Profitabilitas : bagian ini menjelaskan di mana persentase total biaya manfaat yang mengukur pendapatan dikurangi total biaya. Penjelasan ini bisa disimpulkan dari dimensi variabel profitabilitas terdiri dari total pengeluaran, total pendapatan dan total laba.

\section{Model Penelitian}

Berdasarkan kajian teori di atas, penelitian ini mengembangkan sebuah model tentang hubungan antara entrepreneurial marekting dan trust terhadap marketing performance di industri Kerajinan UMKM. Model dalam penelitian ini digunakan untuk melihat pengaruh langsung dari variabel penelitian. Adapun model dalam penelitian ini adalah sebagai berikut. 


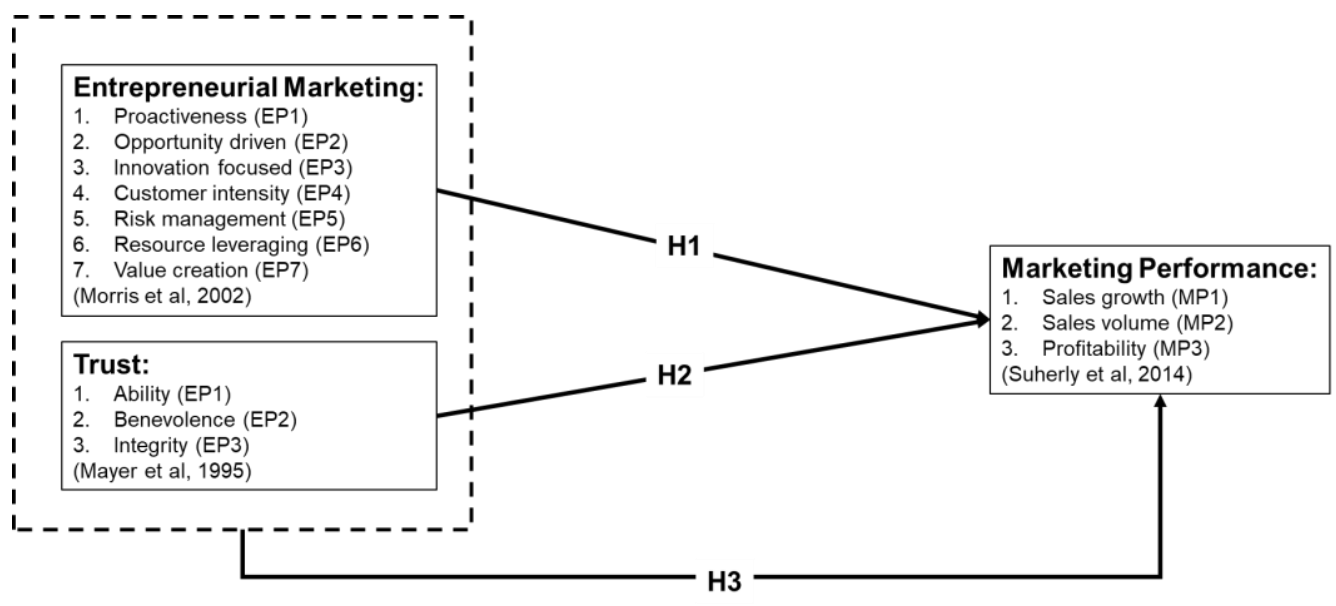

Gambar 4.

Kerangka Penelitian

\section{METODE PENELITIAN}

Data didapatkan melalui pendistribusian kuesioner dengan pertanyaan tertutup. Sampel pada penelitian ini berjumlah 200 responden dan pemilihan responden dilakukan menggunakan metode purpossive sampling. Kriteria responden yaitu UMKM minimal telah menjalankan usaha selama 3 (tiga) tahun. Hal ini dikarenakan dalam pengukuran dimensi kinerja pemasaran terdapat sejumlah indikator tingkat pencapian kinerja pemasaran tiap tahun, sehingga setidaknya selama minimal 3 tahun dapat diketahui kinerja pemasaran UMKM tersebut. Metode analisis data pada penelitian ini menggunakan uji regresi linear berganda yang terdiri dari uji parsial (uji t) dan uji $\mathrm{f}$ dan uji $\mathrm{R}$ square. Variabel dalam penelitian ini meliputi entrepreneurial marketing, trust dan marketing performance. Variabel tersebut akan diukur menggunakan skala Likert pada jawaban skala 1 sampai 5 dan pertanyaan langsung mengenai kinerja pemasaran mereka. Analisis Data dalam penelitian ini adalah menggunakan data primer dan data sekunder.

\section{HASIL DAN PEMBAHASAN}

Responden dalam penelitian ini diklasifikasikan berdasarkan karakteristik: jenis kelamin, riwayat pendidikan, jenis kepemilikan usaha, lama menjalankan usaha, jumlah karyawan yang dimiliki. Aspek-aspek tersebut merupakan hal yang penting yang dapat dikaitkan dengan variabel penelitian. Karakteristik responden tersebut di analisis dengan menggunakan statistik deskriptif melalui program SPSS. Berikut deskripsi data responden. 
Tabel 3.

Deskripsi Responden

\begin{tabular}{|c|c|c|c|}
\hline \multicolumn{2}{|c|}{ Karakteristik } & \multirow{2}{*}{$\begin{array}{r}\text { Frekuensi } \\
118 \\
\end{array}$} & \multirow{2}{*}{$\begin{array}{r}\text { Persentase } \\
59 \% \\
\end{array}$} \\
\hline \multirow{2}{*}{ Jenis Kelamin } & Laki-laki & & \\
\hline & Perempuan & 82 & $41 \%$ \\
\hline & Total & 200 & $100 \%$ \\
\hline \multirow{4}{*}{$\begin{array}{c}\text { Riwayat } \\
\text { Pendidikan }\end{array}$} & SMP & 16 & $8 \%$ \\
\hline & SMA/SMK & 49 & $24,5 \%$ \\
\hline & Diploma & 34 & $17 \%$ \\
\hline & S1 & 101 & $50,5 \%$ \\
\hline & Total & 200 & $100 \%$ \\
\hline \multirow{3}{*}{$\begin{array}{c}\text { Jenis } \\
\text { Kepemilikan } \\
\text { Usaha } \\
\end{array}$} & Milik Sendiri & 163 & $82 \%$ \\
\hline & Usaha bersama teman & 9 & $4,5 \%$ \\
\hline & Usaha keluarga & 28 & 13,5 \\
\hline & Total & 200 & $100 \%$ \\
\hline \multirow{5}{*}{$\begin{array}{c}\text { Lama } \\
\text { Menjalankan } \\
\text { Usaha }\end{array}$} & 3-5 tahun & 14 & $7 \%$ \\
\hline & 6-10 tahun & 31 & $15,5 \%$ \\
\hline & 11-15 tahun & 50 & $25 \%$ \\
\hline & 16-20 tahun & 63 & $31,5 \%$ \\
\hline & $>20$ tahun & 42 & $21 \%$ \\
\hline & Total & 200 & $100 \%$ \\
\hline \multirow{6}{*}{ Jumlah Karyawan } & $1-5$ orang & 64 & $32 \%$ \\
\hline & 6-10 orang & 83 & $41,5 \%$ \\
\hline & 11-15 orang & 27 & $13,5 \%$ \\
\hline & $16-20$ orang & 18 & $9 \%$ \\
\hline & $>20$ orang & 8 & $4 \%$ \\
\hline & Total & 200 & $100 \%$ \\
\hline
\end{tabular}

Dari jenis kelamin terlihat bahwa responden laki-laki sebanyak 118 orang dengan persentase $59 \%$ dan perempuan sebanyak 82 orang dengan persentase $41 \%$. Mayoritas riwayat pendidikan adalah S1 sebanyak 101 orang dengan persentase 50,5\%. Mayoritas jenis kepemilikian usaha adalah milik sendiri sebanyak 163 orang dengan persentase $82 \%$. Mayoritas lama menjalankan usaha adalah 16-20 tahun dengan persentase 31,5\%. Dan mayoritas jumlah karyawan adalah 6-10 orang dengan persentase 41,5\%.

Uji Validitas \& Reliabilitas

\begin{tabular}{llll} 
Variabel & Indikator & Sig. (2 tailed) & Cronbach Alpha \\
\cline { 1 - 2 } $\begin{array}{l}\text { Entreprenurial } \\
\text { Marketing }\end{array}$ & EM1 & 0,000 & 0,633 \\
\cline { 2 - 3 } & EM2 & 0,000 & \\
\cline { 2 - 3 } & EM3 & 0,000 & \\
\cline { 2 - 3 } & EM4 & 0,000 & \\
\cline { 2 - 3 } & EM5 & 0,000 & \\
& EM6 & 0,000 &
\end{tabular}




\begin{tabular}{llcl}
\hline & EM7 & 0,000 & 0,636 \\
\hline Trust & TRS1 & 0,000 & \\
\cline { 2 - 3 } & TRS2 & 0,000 & 0,802 \\
\cline { 2 - 3 } $\begin{array}{l}\text { Marketing } \\
\text { Performace }\end{array}$ & TRS3 & 0,000 & \\
\cline { 2 - 3 } & MP2 & 0,000 &
\end{tabular}

Dari hasil uji validitas dan reliabilitas menunjukkan bahwa indikator yang menjadi alat ukur dalam penelitian ini telah memenuhi kriteria. Sehingga dapat dilakukan uji selanjutnya.

\section{Uji Regresi}

\begin{tabular}{llll}
\hline Variabel Bebas & Koefisien & t hitung & Signifikansi \\
\hline Konstanta & 0,299 & 0,254 & 0,799 \\
Entreprenurial Marketing & 0,284 & 6,087 & 0,000 \\
Trust & 0,323 & 3,837 & 0,000 \\
$\mathbf{R}^{2}$ & 0,353 & & \\
F hitung & 53,678 & \\
Sig. (p value) & 0,000 & \\
\hline
\end{tabular}

Hasil uji regresi dalam penelitian ini menunjukkan nilai konstanta sebesar 0,299, hasil uji t variabel entrepreneurial marketing terhadap marketing performance menunjukkan nilai 6,087 dengan signifikansi 0,000 dan hasil uji t variabel trust terhadap marketing perfromance menunjukkan nilai 3,837 dengan signifikansi 0,000. Begitu juga uji $\mathrm{F}$ yang menunjukkan nilai 53,678 dengan signifikansi 0,000. Dengan demikian 3 hipotesis yang dikembangkan dalam penelitian ini diterima. Selain itu, nilai $\mathrm{R}^{2}$ berjumlah 0,353 atau $35,3 \%$ yang artinya terdapat pengaruh lain di luar entreprenurial marketing dan trust sebesar $64,7 \%$ untuk mempengaruhi marketing performance.

\section{PENUTUP}

Berdasarkan analisis data yang dilakukan didapatkan hasil bahwa entrepeneurial marketing berpengaruh signifikan terhadap marketing performance, trust berpengaruh signifikan terhadap marketing performance, entrepreneurial marketing dan trust seceara 
simultan berpengaruh siginifkan terhadap marketing performance. Ketika Para pelaku UMKM meningkatkan entrepreneurial marketing dan trust akan meningkatkan juga marketing performance dari usaha tersebut. Dalam penelitian ini terdapat keterbatasan penelitian yang dilakukan oleh peneliti. Saran yang dapat diberikan kepada penelitian selanjutnya yaitu diharapkan dapat melakukan penelitian yang lebih luas terutama untuk objek penelitian. Peneliti selanjutnya dapat melakukan penelitian terhadap objek penelitian dibidang yang lain, seperti pelaku UMKM di bidang kuliner dan bidang-bidang lainnya. 


\section{DAFTAR PUSTAKA}

Adnyana, R., and Darma, G.S. (2015). Strategi Marketing Mix, Yield Management, Customer Satisfaction and Occupancy Rate, Jurnal Manajemen \& Bisnis, 12 (1): 92-115.

Bell, S.J., and Luddington, J.A. (2006). Coping with Customer Complaints, Journal of Service Research, 8 (3): 221 - 233.

Dewi, M.V.K., and Darma, G.S. (2019). The Role of Marketing \& Competitive Intelligence In Industrial Revolution 4.0, Jurnal Manajemen \& Bisnis, 16 (1): 1-12.

Kartawinata, B.R., dan Aditya Wardhana. (2013). Marketing Strategies and Their Impact on Marketing Performance of Indonesian Ship Classification Society, International Journal of Science and Research, 4 (2): 69-74.

Kau, A.K., and Elizabeth W. Y. Loh. (2006). The Effect of Service Recovery on Consumer Satisfaction : A Comparison Between Complainants and Non-Complainans, Journal of Service Marketing, 22 (2) 101-111.

Kim J, Dan., Donald L, Ferrin., and H. Raghav Rao. (2003). Antecedent of Consumer Trust in B-to-C Electronic Commerce. Research Collection Lee Kong Chian Scholl of Business, pp. 157-167.

Kraus, S., Rainer Harms., dan Matthias Fink. (2009). Entrepreneurial Marketing : Moving Beyond Marketing in New Ventures, International Journal Entrepreneurship and Innovation Management, Special Issue: 1-20.

Kurniawan, R., Sucherly., and Surachman. (2016). The Influence of Customer Handling on Brand Image In Building Customer Loyalty, International Journal of Scientific \& Technology Research, 5 (5): 113-117.

Kanten, I.K., and Darma, G.S. (2017). Consumer Behaviour, Marketing Strategy, Customer Satisfaction, and Business Performance, Jurnal Manajemen \& Bisnis, 14 (2): 143-165.

Lau, G.T., and Sook Han Lee. (1999). Consumers' Trust in a Brand and The Link to Brand Loyalty, Journal of Marketing Focused Management, 4: 341-370.

Meyer, C. Roger., James H, Davis., and F. David Schoorman. (1995). An Integrative Model of Organizational Trust, The Academy of Management Review, 20 (3): 709-734.

Morgan, R.M., and Shelby D. Hunt. (1994). The Commitment-Trust Theory of Relationship Marketing, Journal of Marketing, 58: 20-38.

Morris, M.H., Minet Schindehutte., and Raymond W. LaForge. (2002). Entrepreneurial Marketing: A construct for integrating emerging entrepreneurship and marketing perspecstives, Journal of Marketing Theory \& Practice, 10 (4): 1-19. 
Muangkhot, S., and Praprukbaramee Ussahawanitchakit. (2015). Strategic Marketing Innovation and Marketing Performance: An Empirical Investigation of Furniture Exporting Businesses in Thailand, The Business and Management Review, 7 (1): 189205.

Mukherjee, A., and Prithwiraj Nath. (2003). A Model of Trust in Online Relationshp Banking, International Journal of Bank Mrekting, 21 (1): 5-15.

Niehm, L.S., Jessica L, Hurst., Jihyeong Son, Ann Marie Fiore., and Amrut Sadachar. (2013). Entrepreneurial Marketing : Scale Development and Validation In The Small Firm Context. Digital Reposiroty, Iowa State University.

Ogbuji, C.N., Sylva Ezema Kalu, Maduenyoghasi., dan Oluchukwu Samson. (2014). The Influence of Brand Extension Strategy on Marketing Performance of Soft Drinks Bottling Firms in Nigeria, American International Journal of Contemporary Research, 4 (1): 266276.

Pavlou, P.A., and David Gefen. (2002). Building Effective Online Marketplaces with Institution-Based Trust, International Conference on Infromation System: 667-675.

Stokes, D. (2000). Putting Entrepreneurship Into Marketing : The Processes of Entrepreneurial Marketing, Journal of Research in Marketing \& entrepreneurship, 2 (1): 1-16.

Suherly., Faisal Affif., Helmi Arief., dan Alexandre Desousa Guterres. (2016). Marketing Performance as The Impact of Marketing Strategy (7P) with Determination of Market Attraction and Company's Resources : Survey on Performers of Tourism Industry in Timor Leste, International Journal of Economics, Commerce and Management, 4 (9): $569-587$.

Walker, R.H., Rod Slater., dan Lester W. Johnson. (2004). Measuring Marketing Performance Against The Backdrop of Intra-Organizational Change, Markting Intellegence \& Planning, 22 (1): 59-65. 